\title{
At the Borders of Non-Work: Poor Female Workers and Definitions of Vagrancy in Early Twentieth- Century Rio de Janeiro*
}

\author{
LERICE DE CASTRO GARZONI \\ Instituto Federal de Educação, Ciência e Tecnologia do Sul de \\ Minas Gerais \\ Campus Poços de Caldas, Avenida Dirce Pereira Rosa, 300, \\ Jardim Esperença - CEP377I3-I00 - Poços de Caldas - \\ $M G$, Brasil
}

E-mail: lerice.garzoni@gmail.com

\begin{abstract}
This article discusses how residents of early twentieth-century Rio de Janeiro, Brazil, defined vagrancy. Commentators on the 1890 Penal Code sought to explain the terms of the article related to vagrancy, article number 399, and its application. Evaristo de Moraes, a lawyer, essayist, and public intellectual at that time, similarly dedicated several works to this topic, as did journalists and literary writers who worked in the press. But these debates in the lettered realm were not isolated from the views and actions of average citizens, a phenomenon that one can observe by reading the criminal proceedings against women who were arrested for repeat offenses against anti-vagrancy laws. In the interventions and arguments of the accused and their defenders, it is possible to observe how vagrancy took on new meanings and how, over the course of time, the relationship between these women and the world of work evolved.
\end{abstract}

In September 1904, Maria Francisca Leonor was detained on the Rua General Pedra in the city of Rio de Janeiro, Brazil. After being held in custody for a short time at the district police station in the Santana parish, she was sent to the Casa de Detenção, Rio's central detention center. ${ }^{\mathrm{I}}$ This was the typical journey taken by those charged under article 399 of the Brazilian Penal Code, which defined "vagrancy" as a misdemeanor.

* This article is a revised and adapted version of: "Nas fronteiras do não-trabalho: trabalhadoras pobres e as definições de vadiagem no início do século XX", Revista Mundos do Trabalho, г:2 (2009), pp. 65-93. Translation: Amy Chazkel.

I. Vagrancy case against the defendant Maria Francisca Leonor; Arquivo Nacional [hereafter, AN], Série processo criminal da 8. ${ }^{a}$ Pretoria do Rio de Janeiro, notation (notação) OR.356r, September 1904 . 
Indeed, anyone who reads through a number of criminal records of this type is given the impression that cases like Maria Francisca's constantly occurred in early twentieth-century Rio de Janeiro. The particulars of the arrests and the individual suspects, the streets on which the events unfolded, and their individual circumstances changed from case to case, but innumerable men and women lived through a saga similar to that of this accused vagabunda - the derogatory word often used to denote a female "vagabond" or "tramp".

Contesting the police officers' assertions about them, many of the women under arrest for this offense nonetheless considered themselves legitimate "workers", and argued that they had been unfairly torn from their daily labor in the course of these proceedings. These women's experiences therefore suggest discordance between the conceptions of work held by the men who wrote the laws to suppress vagrancy, those who applied the law, and the real lives of the women who were labeled as vagabundas. The lack of consensus concerning how to define "work" and the imprecision concerning just what made someone a "vagabond" were directly related.

Critical reflections on the concept of work have been at the center of an international debate among historians during the last decades. In this context, historical studies of vagrancy in different places and periods have involved the analysis of a series of processes affecting workers (in the broadest term), from the modernization of the state and corresponding imperial projects to urbanization and the containment of poverty. ${ }^{2}$ Particularly in relation to post-abolition periods, several studies have shown how the use of laws to inhibit vagrancy formed part of broader efforts by the authorities to discipline and control the population. In Brazil, the Penal Code of 1890 , which defined vagrancy as an infraction, was passed less than a year after the proclamation of the Republic, an event which, in turn, had been directly related to the abolition of slavery in $\mathrm{I} 888$.

To study how lettered men interpreted the articles dealing with vagrancy as well as the application of these laws in a Rio de Janeiro neighborhood at the time, will allow us to reveal the limitations and loopholes of these laws as well as the views of those targeted by them. The relevant documents also make the tensions and conflicts visible which were implied in and fomented through these trials about vagrancy. By treating the legal trials as indicators of how the Republican police persecuted, hassled, and stigmatized the poor

2. See, as a North American gateway to the vast literature, Paul Ocobock, "Vagrancy and Homelessness in Global and Historical Perspective", in A.L. Beier, and Paul Ocobock (eds), Cast Out: Vagrancy and Homelessness in Global and Historical Perspective (Athens, $\mathrm{OH}, 2008$ ), pp. I-34. For an approach to vagrancy in relation to the boundaries of "work" and "non-work", see also Sigrid Wadauer, "Establishing Distinctions: Unemployment Versus Vagrancy in Austria from the Late Nineteenth Century to 1938", International Review of Social History, 56 (201 I), pp. 3 I-70. 
in order to maintain order in a capital which, at the beginning of the twentieth century, went through a process of reform and modernization, the aim is not only to study the intentions of the authorities and the law, but also the views of contemporaries about its existence and application. The focus on women detained for vagrancy furthermore allows us to study how gendered visions about the presence of women in public space, honor, and work were drawn on and resignified by these poor female workers themselves. ${ }^{3}$

Indeed, the vagaries of the definitions of both work and vagrancy in federal legislation during Brazil's First Republic (I889-I930) were the subject of lively debate both among the intellectual elites and among the general population. The difference is that, while legislators and commentators took "masculine vagrancy" as the standard against which they understood their mandate to repress this infraction of the law, police who arrested female vagrants - the vagabundas - were impelled to debate the finer points of morality and instability of certain professions with these women and their defense attorneys. Thus, criminal cases involving women repeatedly arrested for vagrancy allow us to observe some dimensions of gendered social relations that the (male) lettered elites generally silenced.

In the first decades of the twentieth century, although arrests like that of Maria Francisca continued to occur, one can observe changes in the way in which such arrests were understood and contested. To understand these shifts, it is necessary to trace how definitions of "vagrancy", "work", and "non-work" developed and were given new meaning in the course of these criminal cases involving women arrested repeatedly as "vagabonds", paying attention to the arguments made by the different individuals involved in these episodes.

This article is divided into four parts: in the first two the legislation on vagrancy is introduced, and the interpretations of the commentators on the Penal Code as well as of several lawyers are discussed. In the subsequent parts the article analyzes trials against women charged with vagrancy as repeat offenders in the Santana parish of Rio de Janeiro, focusing on the interpretations of the accused and their defenders. In total, I 20 vagrancy court cases against women, all opened between 1905 and 1925 , have been analyzed. Working with cases of repeat offenders offers the opportunity to follow these women over a longer period of time, thus assessing if there were shifts in the way they behaved vis-à-vis the officers during their repeated detentions in the police station.

3. For a discussion of gender issues in relation to tramps, see Lynn Weiner, "Sisters of the Road: Women Transients and Tramps", in Eric Monkkonen (ed.), Walking to Work: Tramps in America, 1790-1935 (Lincoln, NB, I 984), pp. I7 I-I 88; and Tim Cresswell, "Embodiment, Power and the Politics of Mobility: The Case of Female Tramps and Hobos", Transactions of the Institute of British Geographers, 24 (1999), pp. 175-192. 


\section{UNDETERMINED DEFINITIONS: LAWS AGAINST VAGRANCY}

Being arrested for vagrancy was not a privilege, so to speak, of the few in Brazil during the early years of the First Republic. In this era in Rio de Janeiro, ${ }^{4}$ then the nation's capital, vagrancy was one of the most frequent reasons for the arrest of poor workers involved in casual or unstable occupations. From a legal perspective, punishing vagrancy was nothing new in this era. Both in the colonial period when Brazil was still governed by Portuguese legislation as well as in the post-independence period after I 822 (known as the Empire of Brazil) under the Criminal Code of I 830, Brazilian criminal law punished beggars and vagrants. ${ }^{5}$ With the abolition of slave labor in view, public debate about how to control non-work took on new meaning, as can be observed in the discussions that arose around anti-vagrancy legislation in $\mathrm{I} 888$, the same year in which slavery was abolished. ${ }^{6}$ In the Republican Penal Code (Código Penal da República) passed in I 890 , vagrancy came to be defined as a misdemeanor for which anyone could be prosecuted who, according to its infamous article 399, "fail to exercise a profession, trade, or any occupation in which to earn a living, having no means of subsistence and no particular residence in which to live, or who makes a living by way of any occupation prohibited by law and clearly offensive to morality and good custom"?

This apparently simple explanation of the anti-vagrancy article, which turned on the absence of an occupation and a fixed domicile, was, however,

4. According to the census of 1906 , Rio de Janeiro counted 8I I,443 inhabitants in that year $(463,453$ men and 347,990 women). Due to the strong flow of European immigration as well as the internal migration of ex-slaves from other regions in Brazil, the city had experienced an increase of 55.3 per cent in the total number of inhabitants compared to the I 890 census. Again according to the census, of the population in 1906, 25 per cent was foreign. Declared the capital of the colony in the middle of the eighteenth century, Rio de Janeiro made great leaps in its development after the Portuguese Court was transferred to Brazil in I 808 . In this period, the opening of the ports also made the influx of immigrants possible, many of whom established themselves in the city. It was also during these years that a rising number of travelling artists passed through Rio de Janeiro, portraying the city in their works. These paintings, such as those by Jaen-Baptiste Debret or Johann M. Rugendas, often testify to the presence of slaves in daily life. After the abolition of slavery a policy of incentivizing European immigration was adopted, in order to "whiten" the population, which triggered the immigration wave at the end of the nineteenth century mentioned above. The city functioned as capital of the Republic between I 889 and 1960 when the status of capital was transferred to Brasilia.

5. For a more detailed history of anti-vagrancy laws before the First Republic, see Marcelo Badaró Mattos, "Contravenções no Rio de Janeiro do início do século", Revista Rio de Janeiro, I (1993), pp. I6-23.

6. See the discussion of the 1888 project to repress indolence, in Sidney Chalhoub, Trabalho, lar $e$ botequim: o cotidiano dos trabalhadores no Rio de Janeiro da belle époque (Campinas, 2001), pp. $64-89$.

7. Collecção das Lei dos Estados Unidos do Brazil de I890 (Rio de Janeiro, I 890), p. 2734. 
far from being precise at that moment in history. How could one define "profession, trade, or any occupation" when the jobs available to the poorer classes were extremely unstable, such as work in the port or in domestic service? ${ }^{8}$ What possibilities were there for "a particular residence" when urban reforms and increases in the cost of rent led people to seek out provisional housing arrangements, as people have traditionally done?

If the men who made these laws appeared to be at liberty to ignore these particularities of urban life, flattening out a complex reality in which they did not actually participate, those directly responsible for policing the streets were indeed in a more delicate situation. Police officers were not only forced to address these questions every day in their task of patrolling the streets, but they also shared with the working classes much of these living conditions. Although they had the law on their side, its vagueness allowed for a range of different interpretations, not only when enforcing their authority but also when those accused wished to contest their power as police.

In the annotated versions of the Penal Code, which were resorted to either to justify the actions of police or to defend the accused, law-makers and jurists sought a way of characterizing this misdemeanor. They based their discussions, above all, on the details concerning what defined a "profession, trade, or any occupation", and a "particular residence". They tended to complement what was stated in the Code by citing another definition, derived from an appellate court decision (a so-called acórdão) in 1902, according to which:

Vagrancy is a special type of infraction, including under its definition the following elements:

I. Lack of a specific home;

2. Not having the means of subsistence;

3. Not exercising any profession, trade, or any occupation in which one can earn a living. ${ }^{10}$

8. On the instability of those occupations see, respectively, Érika Bastos Arantes, "O porto negro: cultura e trabalho no Rio de Janeiro dos primeiros anos do século XX" (Master's thesis in History, UNICAMP, 2005); and Sandra L. Graham, House and Street: The Domestic World of Servants and Masters in Nineteenth-Century Rio de Janeiro (Cambridge, 1988). On the high rates of unemployment at this time see, among others, Sylvia F. Damazio, Retrato Social do Rio de Janeiro na virada do século (Rio de Janeiro, I996).

9. This question was especially evident in the Santana neighborhood of Rio, where dwelling arrangements were commonly more collective. On the significance and political meanings of collective housing arrangements, see Sidney Chalhoub, Visões da Liberdade: uma história das últimas décadas da escravidão na corte (São Paulo, I990), especially ch. 3.

Io. Acórdão do Tribunal de Justiça de São Paulo, 26 July 1902, Revista de Jurisprudência, VII, p. I7I, cited in Código Penal Brasileiro (decreto $n .847$ de I I de outubro de I890). Posto em dia, annotado de accordo como direito pratico e a jurisprudência dos nossos Tribunais, contendo ainda o 
This definition, as the second item states, makes clear the possibility that having the means of subsistence did not automatically come as the result of having steady work. This led the author of Theoretical-Practical Notes on the Penal Code (Annotações Theorico-praticas ao Código Penal) to conclude that "the individual could have neither a fixed residence nor a profession, job or trade and still not be a vagabond (vagabundo)", adding that "for this [to be judged not a vagabond], one needs only to have an income to sustain oneself". ${ }^{\text {II }}$ With respect to one's residence, he says that, despite the requirement of a "real residence", residence did not necessarily have to be "fixed", nor did it have to "belong exclusively to the individual, it would be sufficient if the person lived in the residence with others". With respect to the profession, the author of this judicial text emphasizes the exigency of "the habitual character of the work", but this does not imply the "continuous exercise of that profession".

In seeking to fashion a useful tool "for those who will have to apply or solicit the application of the penal law", the author ends by laying bare some general gaps in that law. The police found ways to use this lack of definition in the application of the Penal Code to make accusations against whomever they wished. At the same time, the accused in increasing numbers made use of these gaps in the law to defend themselves, questioning the attitudes and the authority of the men who had arrested them.

Returning to the anti-vagrancy articles in the Penal Code, article 399 specifies that persons who were considered "vagrants" had to serve a prison term of fifteen to thirty days and sign a document promising to take an occupation within fifteen days of their release from prison. Article 400 required that recidivists be confined for between one and three years in "penal colonies that shall be founded on the maritime islands or on the borders of the national territory", in addition to having to sign a promise to take a job upon release. The Penal Code thus established the general guidelines, while the task of laying out the details of the procedures on how and where sentences would be carried out fell to laws and statutes that would be written and passed in the following years.

\section{THE GENDERED LETTERS OF LAW}

In all of these definitions and interpretations of the Code, there is no mention of the gender differences in the ways in which the state recognized

prazo referente à prescrição de cada crime, bem como o calculo da graduação das respectivas penas por Affonso Dionysio Gama (São Paulo, 1923), pp. 498-499; and Annotações Theorico-praticas ao Código Penal do Brasil. De accordo com a doutrina, a legislação e a jurisprudência, nacionais e estrangeiras, seguido de um appendice contendo as leis em vigor e que lhe são referentes por Antonio Bento de Faria (Rio de Janeiro, 1904), p. 608.

I I. Annotações Theorico-praticas ao Código Penal do Brasil, pp. 603-608. 
and punished vagrancy, which might create the illusion that male and female vagabonds - "vagabundos" and "vagabundas" - were "equal before the law". Considering article 399, however, it is important to observe that there is a third element in addition to the requirements of a means of subsistence and a fixed domicile: the laws and jurisprudence also refer to, and disqualify, any occupation "clearly offensive to morality and good customs". In the judicial sentences for women arrested for vagrancy, this was a crucial point, since in order to present evidence many police and witnesses turned to arguments related to the honor of the accused, making references to their moral depravity and to their practice of prostitution. The sexual conduct of women, but not of men, thus became one of the criteria used to judge women in a criminal trial.

Female labor also appeared as a problem even when it came to occupations that did not directly call the integrity of women into question. In the end, even in the words of the defendants themselves, the moment when the presence of the accused in the streets had to be justified was rife with tension, even though they were carrying out such tasks related to a domestic activity as the purchase of household provisions. In these cases, both police and defendants seemed to share the difficulty of defining what would be the profile of an "ideal worker". Even though the judicial proceedings themselves may have actually obscured the specificities of the gendered element in these cases, arrests for vagrancy took place in a society informed by fundamentally different conceptions of the presence of men and women in public spaces. ${ }^{{ }^{2}}$

For a long time, scholarship on this topic has discussed the existence of an hierarchical ideal of social organization, in which men are associated with public space and women with private space. At the same time, many studies have emphasized that, in large part, poor women tended to circulate around the streets of Brazil's capital city to perform different types of work or seeking leisure and fun. ${ }^{13}$ The fact that these women's presence in Rio's public spaces was routine did not exempt them from the questioning gaze of their contemporaries. ${ }^{\mathrm{I}}$ It is important to note that the women themselves

I 2. Since the I980s many studies have approached this issue with different objectives and from different theoretical perspectives. Jurandir Freire Costa, evaluating the process of "medicalization of the family" during the nineteenth century, states that "from the point of view of the hygienists, a woman's independence was confined to the house and the possessions and ideas that reinforced the image of the wife-mother". See Jurandir Freire Costa, Ordem médica e norma familiar (Rio de Janeiro, I983 [1979]), p. 260. In her analysis of medical registries from the beginning of the twentieth century, Maria Clementina Pereira noted the tendency to classify as insane those women who defied certain behavioral patterns, such as those who traveled alone or were financially independent; Maria Clementina Pereira Cunha, Espelho do mundo: Juquery, a história de um asilo (Rio de Janeiro, 1986).

I3. See, among others Rachel Soihet, Condição feminina e formas de violência: mulheres pobres e ordem urbana, I890-1920 (Rio de Janeiro, 1989) and Graham, House and Street.

I4. This is evident in the verdicts on sexual crimes at the beginning of the twentieth century, as Martha Abreu and Sueann Caulfield demonstrate. See Martha de Abreu Esteves, Meninas 
did not tend to confront directly or to negate the reigning values concerning honor and morality. Yet, while almost all involved stuck to the prevalent ideals, there was intense debate: at the beginning of the twentieth century both females accused of vagrancy and the police, as well as those called to intervene in the encounters and clashes between them, debated the actions and interventions of these women in the public spaces of the city.

Just as the differences between female and male vagrancy were not made explicit in the Penal Code, the legislation passed after the Code concerning the locations where punishment and rehabilitation would take place, as well as the sentence itself and the manner in which authorities dealt with recidivism, remained silent with respect to the question of female vagrancy. A statute passed in July I 893, for example, stipulated the creation of a penal colony "for the correction by labor of vagrants, tramps, and capoeiras who were arrested and tried in the Federal District". ${ }^{\text {Is }}$ The issue of work while serving a sentence would be taken up again in the law of 1902, which contained provisions for the creation of "one or more penal colonies for rehabilitation through labor and education", ${ }^{16}$ and in the decree of 1908 , specifically aimed at the reorganization of the Dois Rios Penal Colony. The latter law contained provisions for "forced labor" that aimed at "moral rehabilitation [...] to awaken the sensation of freedom and the habit of self restraint". ${ }^{17}$

According to these legal sanctions, arrests for vagrancy were not merely punitive since they prescribed "correction" not only through the imposition of forced labor but also through the gradual transformation of prisoners into disciplined workers. The succession of these laws and decrees, with their vague and repetitive clauses, suggests the slow pace at which law-makers were able to bring the concrete conditions necessary for these laws' execution into fruition, in other words the penal colonies and the penal regime established there. It is evident, though, that work played a crucial role in interventions against those accused of vagrancy, which, as we have seen, could be more ambiguous and subject to unfavorable interpretations in the case of women when compared to their male counterparts.

Although the Penal Code established the possibility of various gradations, most of those found guilty of vagrancy, especially at the very beginning of the

perdidas: os populares e o cotidiano do amor no Rio de Janeiro da Belle Époque (Rio de Janeiro, 1989); and Sueann Caulfield, In Defense of Honor: Sexual Morality, Modernity and Nation in Early-Twentieth Century Brazil (Durham, NC, 1999).

I 5. Decreto n. I45, I I June I 893, article I, quoted from Collecção das Lei dos Estados Unidos do Brazil de I 893 (Rio de Janeiro, I894), p. 45. Capoeiras refers to practitioners of the syncretic AfroBrazilian martial art/dance style that developed in Brazil in the nineteenth century and was formally criminalized in the 1890 Penal Code.

16. See item IV, article I, lei n. 947, 29 December 1902, quoted from Collecção das Lei dos Estados Unidos do Brazil de 1902 (Rio de Janeiro, 1903), p. I Iо.

I7. See paragraph I, article 63, decreto n. 6994, I9 June 1908, quoted from Diário Oficial da União, Seção I, 23 June 1908, p. 424I. 
twentieth century, received a standard sentence of twenty-two days and a half of incarceration in the Detention Center (Casa de Detenção) or, in the case of repeat offenders, two years in the Dois Rios Penal Colony on Ilha Grande, an island off the coast just over I 50 kilometers west of the city of Rio de Janeiro. ${ }^{\text {I8 }}$ Although men and women served time separately at each of these prisons, the lack of separate buildings for each sex could create difficulties for the institutions' respective administrators. ${ }^{19}$

At the same time, on the administrative side of things, employees of different ranks such as those responsible for the registration of violators of the laws against vagrancy in the Office of Identification and Statistics (Gabinete de Identificação e Estatística) were already governed by specific regulations in their dealings with female criminals. This institution was established in 1903 and centralized the data on those accused of any crime or contravention. This allowed the initiator of any criminal proceeding access to a "record of antecedents" for each defendant. By means of this record one became familiar with a person's entire trajectory as he or she meandered through the criminal justice system, recording the police station where the arrest took place, the date and number of occurrences, the type of crime, and whether the person had completed his or her sentence. In vagrancy cases, this was a new and much more efficient way of determining who was a repeat offender than consulting the sworn statement, mentioned above, "to take up a job". ${ }^{20}$

The registry forms produced by the Office of Identification and Statistics contained a section on the physical description of the detained that included, at times, "anthropometric observations": body measurements that criminological theories suggested were indicative of the criminal tendencies of each defendant. ${ }^{2 \mathrm{I}}$ The fact that women were being subjected to these measurements, and were obliged to partially strip under the gaze of functionaries of the Office, was a topic of controversy for quite some time. ${ }^{22}$

I 8. For the discussion of the possibilities for gradations in sentences, see Annotações Theoricopraticas ao Código Penal do Brasil, p. 6 1о.

19. On the absence of colonies destined exclusively for women and the way they were characterized in the reports of the administrators of the Colonia Correcional de Dois Rios, see Myriam Sepúlveda dos Santos, "A prisão dos ébrios, capoeiras e vagabundos no início da Era Republicana”, Topoi: Revista de História, $5: 8$ (2004), pp. I 38-169, I 57-I 58.

20. To understand the Office's attributions and how these "records of antecedents" were produced, see articles 52 to 68 of decreto n. 4756,5 February 1903.

2I. There is, of course, a huge scholarly literature on the history of "anthropometric measurements" in relation to criminological discourse. Among the most insightful is still one written by a non-historian: Stephen Jay Gould, The Mismeasure of Man (New York, I98I), especially ch. 4. 22. In 1906, Senator Barata Ribeiro questioned these identification practices aimed at women, discussing the notion of "dishonor" for the "tramps". See Olívia Maria Gomes da Cunha, "The Stigmas of Dishonor: Criminal Records, Civil Rights, and Forensic Identification in Rio de Janeiro, 1903-1940", in Sueann Caulfield, Sarah C. Chambers, and Lara Putnam (eds), Honor, Status and Law in Modern Latin America (Durham, NC [etc.], 2005), pp. 295-3 I 5, 295-296. 
While the legislation suggests that both male and female "tramps" were subject to the same criteria of guilt and punishment, the detention of women involved a series of differentiated problems related to the maintenance of a certain "moral order", which was reflected in the way these accused women and their defenders conducted themselves in front of the police authorities.

To understand the dynamics of these legal cases, it is necessary to remember that this arsenal of definitions and procedures concerning vagrancy fell within the responsibilities of the Chief of Police and his commissioners. Right at the beginning of the Republican period, law 628 of October I899, known as the Alfredo Pinto law, granted the police jurisdiction and authority over certain types of misdemeanors mentioned in the Penal Code of I 890 , including vagrancy. This same law regulated the procedures as they were carried out in police stations:

Once the arrest is made the auto [formal statement] shall be promptly drawn up, in which first the defendant would be profiled, and two or three witnesses would provide their testimony, and immediately thereafter the authorities would receive the defense statement either in written or oral form. On the same day, a maximum of three witnesses for the defense shall testify and, once the defendant is questioned, the allegations and documents that he submits shall be immediately forwarded to the appropriate magistrate for him to render a decision. ${ }^{23}$

The language used in this law - "promptly", "next", "on the same day" attest to the pace with which the police authorities were to proceed. In transferring the power to conduct proceedings against those accused of vagrancy to the police, there was an intention to make certain that little time would elapse between the moment the person was caught in flagrante delicto and the time the judge issued a sentence. Consequently, these judicial records were made up of only three sections: a statement describing the arrest, the records of the interrogation that took place in the police station, and the sentence which was pronounced in the jurisdiction of the judge. In contrast with other types of criminal records, in vagrancy cases the established procedure of an investigation in the police station, followed by a new round of depositions in the local police district was not observed. Instead, the statements made in the police station were final, the judge thus relying exclusively on them to evaluate each case.

Often, the judge never laid eyes on the defendant; he simply read the various official statements and then passed his sentence, even though this practice was illegal. ${ }^{24}$ The responsibility for these judicial procedures fell to

23. See Collecção das Lei dos Estados Unidos do Brazil de I 899 (Rio de Janeiro, I900), p. 38. 24. See article 6, section 5, of law no. 628 of 28 October I 899: "Once the formal statement [auto] is presented to the judge, the latter will promptly summon the accused to present himself, within a strict time limit of 24 hours after the summons has been issued, to request those legal measures which he sees as necessary for his defense. These measures have to be decided upon within the subsequent 24 hours and in the presence of the accused [my italics] and, if he does not request 
the police district chief (delegado) of each jurisdiction, which meant that the same police officers who made the arrests for vagrancy on the city's streets were also directly involved in constructing the cases against vagrancy suspects. This type of common practice shows how the police also held certain judicial powers. Despite this apparently clear-cut picture, it is worth noting that low-ranking policemen on the one hand and "female tramps" and their counsels on the other regularly debated and negotiated the boundaries between vagrancy and work, vagrancy and virtue, vagrancy and guilt, among many other socio-cultural issues, offering different interpretations for common routines.

\section{THE MAKING OF A VAGRANT}

Involved in legal questions as both a practising lawyer and an essayist, Evaristo de Moraes, one of the most eminent public figures of the first decades of the twentieth century, did not hesitate to voice his opinion on the question of vagrancy. In I 92 I, he published his Ensaios de Pathologia Social. Vagabundagem, Alcoolismo, Prostituição, Lenocínio (Essays on Social Pathology. Vagrancy, Alcoholism, Prostituion, Pimping). ${ }^{25}$ Most of the three-part book deals with prostitution, and throughout the work he criticizes the legislation relating to this and the other subjects mentioned in the title, pointing out its failings and suggesting changes. At the end of the nineteenth century, he had begun his career as a rábula (a kind of paralegal) and involved himself in the defense of unionized workers and prostitutes who were being evicted from the center of the city. By the time his essays were published, de Moraes was already a lawyer who enjoyed widespread prestige and projection on the political scene. ${ }^{26}$

Upon introducing the theme of "vagrancy", he considered that to deal with this "problem" it was necessary to invest in prevention, assistance, and repression. In Brazil, however, he alleged that only the latter was taken care of and unsatisfactorily so, citing cases in which clauses of the Penal Code and the laws of 1893, 1902, and 1908 had been applied. After these

anything or does not appear before the judge the judge should proceed to an immediate verdict." Another fundamental difference was that those accused of vagrancy remained in prison until the judicial proceedings. This did not occur with the defendants in other types of cases; from the jail in the police station the "vagrants" were sent to the Casa de Detenção, where they were identified by the Gabinete de Identificação e Estatística and awaited the completion of their criminal files.

25. Being poor and seen as a racially mixed mestiço, Evaristo de Moraes began his professional life working as an advocate even before he was formally trained in law. Known for defending workers, and an active trade unionist, he became one of the country's foremost specialists in criminal law; Evaristo de Moraes, Ensaios de Pathologia Social. Vagabundagem, Alcoolismo, Prostituição, Lenocínio (Rio de Janeiro, I92I).

26. On the career of Evaristo de Moraes, see Joseli Maria Nunes Mendonça, Evaristo de Moraes: tribuno da República (Campinas, 2007). 
considerations, de Moraes went on to treat the classification of vagrants, dividing them into three groups: the crippled and ill, the accidentals, and the professionals. ${ }^{27}$ In so doing he sought to define with precision what the laws had not been able to: who, in the final analysis, was a vagrant?

According to de Moraes, most vagabonds fit into the first category, calling for the "intervention of medical science". In his view, all who were indicted of, not just those formally charged with vagrancy, should undergo a specialized medical examination. Defending himself from possible criticism that this argument might bring up, he assured his readers that rather than "subordinating justice to medical science", his recommendations would make judicial procedures more just.

The second group was the "accidental" vagrants, made up of unemployed or ex-convicts, who were able-bodied individuals with no possibility of employment. Here, de Moraes commented on the relationship between vagrancy and the unsteadiness of certain unskilled jobs:

[...] the workers who are employed in certain inferior services, which the English term unskilled, where getting hired is uncertain, fluctuating and poorly paid. These workers, without special skills, and almost always unaffiliated with unions, suffer, more than the others, the vicissitudes of work, contributing greatly to the ranks of the vagrants. They are unskilled porters, dockworkers, construction workers, who work one day out of two or three, without stability. Having no savings, not having the assistance of powerful unions, they exist in a permanent crisis. Their transformation into vagabonds depends on a simple, accidental eventuality. ${ }^{28}$

The lack of security, union affiliation, and savings would explain how easy it was for these workers "lacking special skills" to become vagabonds. De Moraes used the English expression unskilled and listed some jobs that fit this profile but he failed to acknowledge that the majority of Brazilian workers made their living this way, as the censuses of the time or a simple stroll through the streets of the capital demonstrated.

Another cause of "accidental vagrants" was the inadequate arrests and policing of persons considered tramps:

In Brazil, there must be countless tramps raised and maintained by the prison. There must be an enormous proportion of wretches who became idlers and definitely were absorbed into the army of vagrants, due to their entrance and permanence in our poorly cared for prisons and from the resulting police

27. Italics according to the original, the notion of "unskilled" appearing in English. As he later mentions, this division is not of his own making but reproduces a classification that was sanctioned in the fifth International Prison Congress, Paris I895. Founded in the United States in I 870, the International Prison Congress also involved several European countries. Its goal was to encourage the exchange of information about prison administration as well as the prevention and treatment of crime; Moraes, Ensaios de Pathologia Social, p. I7.

28. Ibid., p. 19 . 
vigilance, so foolish and ineffectual [...]. Imagine an unemployed worker, with no strong friendships, no resources, no family. Rounded up unexpectedly in the police dragnet, subjected to the monstrous judicial proceeding already described, forced to endure a sentence of six months of confinement in the depraved [penal] Colony. Upon release, he remains under the surveillance of the Police [...] and already socially declassified; he remains, from then on, a prisoner of the Police, a simple number of the Anthropometric Office, making it impossible for him to find work, in two words - a forced vagrant $[\ldots] .{ }^{29}$

The repeated arrests, de Moraes argued, made any form of employment impossible owing as much to the stigma of a person becoming "socially non-existent" as to his arbitrary persecution as a "prisoner of the police". Here, de Moraes emphasized the national scope of this type of problem, strongly criticizing the Brazilian police and its methods. ${ }^{30}$ Repression, and moreover this type of repression, would be inappropriate for the "accidental vagrants" who, in short, could not be responsible (and as a result punished) for their condition. The distinctions drawn by the author and his actions as a lawyer reveal his efforts to protect these social outcasts, who became recurring victims of injustice and discrimination.

Throughout his discussion of vagrancy, Evaristo de Moraes focused on the men who were arrested and accused of this misdemeanor; none of his examples referred to women. Yet the situations that he described, such as unstable work or repeat offences, were common to both male and female "tramps". In the daily arrest registry of the Santana police station, ${ }^{3}$ the majority of the female defendants declared that they were employed in

29. Ibid., p. 23 , italics in the original.

30. Broadly understood, the author does not consider that this is an exclusively Brazilian problem but one that is accentuated in Brazil, as is evident in the following passage: "[F]oreign writers who bitterly censure the police in their countries, because of the constant persecution of ex-prisoners, would have occasion for more severe reflections, if they considered the absurd actions of the police, commissioners and agents of our police here: in the capital of the republic"; ibid., p. 23.

3 I. According to the decree no. 4,763 of 5 February 1903 regulating the police service in the Federal District, the city of Rio de Janeiro was divided in twenty urban districts, each with a police station. The district police station of Santana was located in the parish of the same name which stretched from the Campo de Santana (also known as the Praça da República) to the sea, and which was known, from the second half of the nineteenth century and due to the high number of AfroBrazilians residing there, as the "black town". This part of Rio was also characterized by a great diversity of immigrant workers of varying origin. Between 1900 and I9I0, Santana, together with the parishes of Santa Rita and Espírito Santo, made up 23 per cent of Rio's total population. The Santana police station was thus localized in one of the most densely populated parts of the city at the time, a fact which translated into a high number of trials for vagrancy. The extensive amount of police documentation conserved on vagrancy shows that this issue was given special attention by the police in this period. With numerous poor workers living there already, it also constituted one of the alternative domiciles for those who had been expelled from the more central areas when these were reformed. Santana thus brought persons of diverse origins and ethnic backgrounds together who, often under the eyes of police officers, met in the countless taverns and collective housing arrangements scattered over the area. 
"domestic service", which could be considered one of the "inferior jobs" that were noted for instability and a lack of collective organization. In the judicial records for vagrancy cases, as we will see, many women who were treated as "well known tramps" alleged that they were the victims of police persecution (and were backed up by their lawyers in these allegations). The situation of women thus corresponded to the one described by de Moraes for men. His omission of women was also manifest in his discussion of the third category, "professional vagrants": "[T] $]$ he individual who, without a fixed abode and not having means of support, does not exercise any skill or profession despite being able-bodied and if offered the chance to work [such an individual] constitutes, indeed, a social threat." ${ }^{22}$

After lengthy reflections on people who were unjustly found guilty, de Moraes apparently tended to agree with the repression of those who constituted a "social threat". The most disquieting aspect of this argument is that that he did not furnish examples of who these "professional vagrants" were and how to distinguish them in practice. He did not address the issue that in Brazil, voluntary vagrants or not, only the poor were tried for vagrancy. Also, with this stance de Moraes revised his own position previously described which called for vagrancy not to be repressed in cases of "accidental vagrancy".

Taken together, de Moraes' classifications and his arguments are close to the positions of some of the commentators on the Penal Code. In the 1904 volume and in another from 1923, the authors recognized that vagrancy could only be punished if there was "conscious choice", that is, the conscious adoption and free choice of a certain way of leading one's life. Thus, those who could not work or were unable to find employment, a condition that one of the commentators called "necessary vagrancy", should not be punished. Both commentators, as well as Evaristo de Moraes, recognized, however, that vagrancy which "disturbed the peace", or was "socially dangerous" could not go unpunished.

This reading of the Penal Code indicates a way of understanding vagrancy through a clear distinction between work and non-work, demonstrating a conception of work and non-work quite alien to the experiences of the working classes at that time, whose daily labor and dwelling arrangements were much more complex than this dichotomy might suggest. Wavering between incorporating some arguments and criticizing others that served to repress persons labeled as vagrants, these men seemed to place themselves in a delicate situation, at once reinforcing and questioning the way the police applied the law. ${ }^{33}$

32. Moraes, Ensaios de Pathologia Social, pp. 28-29.

33. Concerning Evaristo de Moraes, Joseli Mendonça considers that "while incorporating many ideas that justified measures to segregate the poor classes - seen as dangerous because they were 
The debate in which these men participated also appeared neutral in terms of gender, not only by omitting examples referring to women, but also by taking male vagrancy as standard, supposing that the criteria for redefining this misdemeanor were the same regardless of the sex of the accused. This is especially curious in the case of Evaristo de Moraes who, as we mentioned, had not only acted as a counsel for the defense of prostitutes, but had also devoted an entire section of this book to the theme of prostitution. Moreover, he was an experienced lawyer in cases involving women and was possibly acquainted with the particular agenda of these judicial proceedings as well as the relevant arguments in the prosecution or defense of women. In the debate over vagrancy, however, he made no reference to "prostitutes", even though many of the cases he describes were related to this group.

By adopting a gender-neutral stance, Evaristo de Moraes and the aforementioned commentators bypassed especially controversial issues in the judicial proceedings against recidivist women vagrants. One of these points of controversy was the definition of occupations that were "offensive to morality", one of the criteria of article 399 of the Penal Code. Another concerned the definition of legitimate trades for women as well as the boundaries between work and non-work with respect to female activities. Thus, the experiences of the "female vagabonds" unveil dimensions of their daily activities that obviously exceeded the limits of the intelligentsia's discussions about vagrancy. The realities of the legal proceedings, of accusation and defense, however, show a different picture: on the one hand, the legal definitions and the interpretations of the laws and of the Penal Code itself served as reference points in debates between women accused of vagrancy and the police. On the other hand, the "vagabonds" and their attorneys presented different interpretations of both work and the range of occupations appropriate for women, thus broadening our understanding of their relationship with the world of labor. In the following, some of these cases will be analyzed.

\section{WHAT THE FEMALE TRAMPS SAID}

This imbroglio of legal definitions that were applied either to defend or to condemn vagrancy in early twentieth-century Brazil could be appropriated or redefined during the judicial proceedings against recidivist women vagabonds. One of the main controversies that vagrancy arrests generated arose from the way in which each of these women referred to herself at the time of her arrest. What, in the final analysis, constituted vagrancy in flagrante delicto? The arresting officers used standard terms on the official penal justice"; see Mendonça, Evaristo de Moraes, p. 325 . 
forms. After providing basic information about themselves, they stated where and when they had arrested the defendant, who most frequently had been caught in the act of "doing nothing", "wandering around", "walking around", "being a flaneur", or "vagabonding" through the streets. What incriminated them was not the place or the time of day when they were caught in the act, but rather the fact that they committed this act regularly, as a habit. ${ }^{34}$ There was, moreover, the presupposition that these male officers of the law had previous knowledge of those women and, therefore, could attest to the applicability of elements of article 399 of the Penal Code, namely that the police officers knew "with their own certainty" that the women had no profession or fixed abode. And this was the formulation that arresting officers typically invoked to justify the arrest of women accused of vagrancy.

Sometimes, the arresting officers added that the defendant was disorderly or part of an orgy, was walking around "openly as an idler", or was a "habitual drunkard". Certainly, these epithets were not used randomly; their invocation depended on the circumstances of the arrest, the identity of the accused, and her previous relationship with the police. In any event, these allegations enable us to have a general idea as to how the arresting officers justified (and perhaps understood) their actions. The witnesses' testimonies in these cases usually followed this same script, although one can discern other nuances and tensions in their statements.

The accused women who were able to speak in their own defense at the end of the formal statement documenting their arrest (auto de prisão), related their own versions of their lives and the conditions under which they had been arrested. At times they simply inverted the statements of the arresting officers and the witnesses, denying the terms of article 399. In one trial from I905, a certain Lídia de Oliveira Ramos testified that:

$[\ldots]$ it is untrue what is alleged against her by the officer who arrested her and by the witnesses, that their ill will against the accused woman could [illegible] to this falsehood, for the accused is a working woman, from which she earns her living, and has a fixed abode, and does not comprehend how she can be accused of being a tramp; thus, she has been unjustly detained. ${ }^{35}$

Similarly, in 1906 Rita de Cristo Rangel testified at one of her arrests that:

$[\ldots]$ she is not disorderly, a tramp, or a woman of ill repute, since she usually has a job and with the products of her work she pays for the house where she lives. That she already declared where she resides and that it would be easy enough to verify

34. It is worth emphasizing that discussion regarding the time of arrest, as well as the "hours" the accused were usually seen on the streets, took nevertheless a prominent place in some vagrancy cases. See processos with the notations OR.4070 and OR.4050, both from June 1905, and 6Z.834I from February 1924; AN, Série Processo Criminal da 8. Pretoria e da 3. ${ }^{a}$ Pretoria Criminal, Rio de Janeiro. 35. Vagrancy case against the defendant Lídia de Oliveira Ramos et al.; AN, Série Processo Criminal da 8. ${ }^{\text {a }}$ Pretoria do Rio de Janeiro, OR.4I 49, March 1905. 
this; that she gave the police no reason to have arrested her and judged her for vagrancy. ${ }^{36}$

Lídia and Rita, as they defended themselves in these formal statements made after their respective arrests, not only asserted that they had occupations and residences, but also declared themselves to be hard-working and decent women. They thus argued that their acts could not be defined as vagrancy, or that they had given no cause to be arrested as tramps, and that they had been unfairly accused. It seems possible to imagine that the women documented in these arrest records commonly defended themselves by asserting that they were the opposite of the legal definition of a "tramp", inverting the accusations of the arresting officers and witnesses. A close scrutiny of the documentation, however, reveals that this tended not to be case, and indeed one can observe many other ways of expressing themselves and behaving before the police in these women's defense statements.

It was not uncommon for a defendant to state that, "she did nothing to get arrested", or had "nothing to defend herself for". ${ }^{37}$ The idea that only those who had done something wrong got arrested showed a certain lack of understanding about a type of infraction in which precisely the act of "doing nothing" - not working, idling about - could be a reason for arrest. But these women's statements could also be interpreted as demonstrating a certain indifference about the opportunity to defend themselves, or, on the contrary, as a confrontational stance towards the police who conducted the proceedings.

This can be seen in the testimonies in which the accused women not only admitted that they had previously been arrested but also linked this fact to their expectation of an acquittal. In this respect, it is noteworthy to revisit the case of Maria Francisca Leonor, the defendant in a vagrancy case already mentioned, and the statements that she made both at the time of her arrest and when she was interrogated on the following day. On the first occasion, she stated that:

$[\ldots]$ she has not been working due to illness and has no home because she has no money to pay for lodging and she must be released, just like she was by the police in Meyer [the neighborhood where she previously arrested] after answering charges and serving twenty-two days in detention.

She was asked where she had been at the time of arrest and responded that "she had sat herself down in a doorway because she was tired and was sleeping when arrested and brought to this police station”. In her defense in response to the case being mounted against her,

36. Vagrancy case against the defendant Rita de Cristo Rangel; AN, Série Processo Criminal da 8. ${ }^{\text {a }}$ Pretoria do Rio de Janeiro, OR.4730, May 1906.

37. See, among others AN, Série Processo Criminal da 8. Pretoria do Rio de Janeiro; OR.3344, September 1904, OR.4174, December 1905, OR.5104, March 1907, and OR.8505, September I9II. 
[...] she responded that she will be released and so she does not need to defend herself because she didn't kill or rob and was arrested as she was sleeping and therefore will not be found to be a criminal and should be released just like the judge did in Meyer. ${ }^{38}$

For Maria, her arrest was unjustified. She had not chosen to be without a job or a home; instead, a number of contingencies - her ill health and lack of money - over which she had no control had befallen her. In contrast with the policeman who had arrested her, she saw no harm in stopping for a nap in the street. In spite of what the authorities said, Maria classified herself as an "occasional" vagrant, to use the terminology of Evaristo de Moraes and the concept that had become common among commentators on the Penal Code of 1890 . It is interesting to observe that in both the version of the Code published in 1904 and the one published in I923, these commentators cited an acórdão - a judicial decision rendered by an appellate court - by which "being found asleep on a public thoroughfare in of itself does not signify vagrancy". 39 There is no way of knowing if the accused in question had access to that decision, but the fact is that she employed her own conceptions to make the same assertion. She even emphasized that "she did not kill or rob", and for this reason "she did not judge herself a criminal".

Owing to her prior experience in another district in Rio, Maria believed that she would be acquitted again. What she apparently did not understand was that twenty-two days in the Casa de Detenção did not necessarily constitute an acquittal. On the contrary, imprisonment for twenty-two days was the sentence that judges usually applied in cases of vagrancy, which might mean that she had actually been convicted in Meyer, and not acquitted as she claims. Beyond that, she also apparently did not realize that, by pointing to the arrest in Meyer, she was actually risking being considered a recidivist and thus being imprisoned for a longer term. In trying to defend herself, she provided details that could have further complicated her situation.

Maria's stance in the trial contrasted to a certain degree with that of Olivia Maria de Oliveira. ${ }^{\circ}$ Olívia had a long record of arrests in the Santana police station where she used a different name each time. In one of the proceedings, the arresting officer and the witnesses referred to this fact as part of the accusation. In her defense, Olivia admitted "that it is true that she was arrested and brought to this police station under the name of Olivia de

38. Vagrancy case against the defendant Maria Francisca Leonor; AN, Série processo criminal da 8. ${ }^{a}$ Pretoria do Rio de Janeiro, OR.3561, September 1904.

39. Acórdão da Câmara Criminal do Tribunal Civil e Criminal do Distrito Federal, 7 October 1903, O Direito vol. 92, p. 61 8, cited in Annotações Theorico-praticas ao Código Penal do Brasil, p. 608; and Código Penal Brasileiro, Decreto n. 847, i I October i 890, comentado por Affonso Dionysio Gama, p. 499.

40. Vagrancy case against the defendant Olívia Maria de Oliveira; AN, Série processo criminal da 8. ${ }^{2}$ Pretoria do Rio de Janeiro, OR.4173, February 1905. 
Oliveira and Olívia Maria da Conceição, but that she was drunk in August and September when arrested and is not a tramp and was unjustly arrested then and now". When interrogated, she admitted to having "no home, having been arrested in the boarding house where she slept", and, asked why she changed her names, she "responded that she changed her name to avoid being convicted and sent to the Penal Colony". Finally, when asked if she had evidence in her defense, she "responded that in the local judicial district (pretoria) she would defend herself because she has to be released, and if she is convicted to the Colony, then not to die".

Clearly, using made-up names had little to do with being drunk, since it was an artifice used to hide repeat offenses and therefore to avoid serving two years in the Penal Colony. But there is a tone of disdain when she says she will not defend herself before the police but would appear in the judge's jurisdiction (pretoria), since she believed that the judge would free her, concluding that, if sent to the Colony, "then not to die". Tragically, these words eventually would turn out to be wrong, since at the end of I905 she died in the Casa de Detenção before her transfer to serve a two-year sentence in the Penal Colony and while facing other charges for vagrancy. In contrast to Maria, Olívia's other arrests had acquainted her with the judicial process and, as a consequence, another means of dealing with it.

Yet also Olívia, when declaring that she had spent the night in a boarding house, was apparently unaware that this fact could be used against her to reinforce her image as a minor offender or a prostitute, as occurred in the witness testimony in other trials. ${ }^{4 \mathrm{I}}$ In contrast to the author of the previously discussed Anotações of 1904, the police were somewhat suspicious of transient and shared housing arrangements. In truth, the police assigned various types of judgment to these housing arrangements, a fact which the commentator of 1904 had not taken into consideration. Such information on housing could be brought up in the criminal proceedings as indications of a misdemeanor - notwithstanding that many police officers themselves lived in very similar collective housing arrangements, like inspector Pedro J.L. Bairão who arrested Maria Francisca at the end of 1904 .

In their routine, the police appear to have had a hierarchical view of the different types of transient and collective forms of housing, judging them based on the degree of permanence of the inhabitants. Places like the hostals (bospedarias) - the word used in these police records in Olivia's case - with a large turnover of occupants were continually denigrated and associated with immorality, according to the police escorts. With regard to Olivia, 
either she was unaware of the negative implications of admitting that she lived in collective housing or, more likely, she could not deny that she lived in a hospedaria, given her long history of interaction with the police in that district. In any event, her declaration is one indication that she did not care much about what the authorities who had arrested her thought or did, and that she was, like Maria, more concerned with the opinion of the judge.

In the vagrancy arrest records involving female defendants, then, one can find numerous women who defined themselves as hard workers, reinforcing and inverting their accusers' preconceived ideas, and one can also find those who saw no problem in admitting to previous arrests. In the early years of the twentieth century, it was common for judges to dismiss criminal cases that were initiated in the police stations for non-compliance with legal formalities. This routine seems to have led recidivists to doubt the ability of the police to have them convicted. From the middle of the rgros on, these judicial proceedings would become more serious and formal.

The police stopped lumping more than one person into a single criminal case, known as canoa (canoe) in the slang of the time. ${ }^{42}$ Yet, they continued to rely on the illegal use of colleagues as witnesses. Better preparation of the police in formal aspects of criminal cases led to a reduction in the number of cases that were dismissed in the following years. ${ }^{43}$ This process of formalization, however, also had another effect: over time, the voices of the accused women became more and more silenced, since they were hardly given a chance to defend themselves any more, their answers to questions in the proceedings being reduced to standardized monosyllables. Instead it was men who increasingly were speaking on their behalf.

\section{MALE VOICES IN DEFENSE OF WOMEN VAGABONDS}

The men who represented female vagrancy defendants tended to take other approaches when making arguments on their clients' behalf, as can be seen in the documents that they directed to the local judges in charge of these cases. Whether they were court-appointed lawyers, paralegals, or acquaintances of the accused, they made use of different strategies to prove the defendants' innocence. For instance, the lawyers questioned what it meant to be caught in the flagrant act of vagrancy, arguing that it was not illegal to amble through city streets. According to Martinho José dos Prazeres in a

42. According to Gíria dos Gatunos Cariocas, a dictionary of the time about Rio's argot, canoa and canastra have the same meaning: "operation organized by the police to round up thieves, troublemakers, and tramps". See Elysio de Carvalho, "Gíria dos gatunos cariocas (vocabulário organizado para alunos da escola de polícia)", Boletim Policial, 4, 5, and 6 (I912), pp. I68-I8I. I am grateful to Professor Sidney Chalhoub for this reference.

43. Of the sentences in the judicial records consulted here, dating between I905 and I9I I, 44 per cent were dismissed due to "formal irregularities". Between I9I 2 and I925, this fell to I 9 per cent. 
I 904 judicial proceeding: "Strolling around the Republic Square (Praça da República) is not the basis for either accusation or conviction, because no law has ever appeared that forbids the freedom to stroll around and, therefore, any of the accusations made against these women do not stand." 44

Some years later in I9ıо, Serapião Alcides de Figueiredo employed similar arguments:

The accused woman was charged with vagrancy. The formal statements made after her arrest indicate that she was arrested as she walked around without a specific destination, etc.

On what basis can the arresting police prevent the accused woman from enjoying a stroll, taking away her freedom, shutting her up in the jail of the police station and then sending her to the Casa de Detenção?

The accused woman was making her way peacefully, she was not practicing the slightest infraction, she did not have to give the least explanation to the police about whether her stroll had a specific destination or no destination at all, she was exercising a right sanctioned in law, which grants freedom of movement independent of a passport or other forms of documentation to all Brazilians and foreign residents and allows them the freedom of transit throughout Brazilian national territory; and the place where the accused woman was arrested is not a neutral [i.e. a legally exempt] zone governed by special laws and regulations, governed dictatorially by the czarist sovereignty of police authority in its absolute despotism, it is part of our national communion and is governed by the general laws of the nation. The arrest of the accused woman is an attack against paragraph I 3 of article 72 of the Federal Constitution, a law that is in full force, that establishes [the conditions for] the legal arrest of an individual; the present case does not constitute a just cause [in view of this law], it is a proven, flagrant declaration of police violence with all of the arbitrariness associated with it. ${ }^{45}$

Despite differences in their modes of expression, the authors of these two passages used the same argument. What the police saw as "vagrancy" these men saw as a "stroll" - something which was completely the opposite of a misdemeanor and therefore beyond the reach of the police. In this sense, the choice of a certain language in reference to the applicable legislation, especially in the second passage above, was used to delegitimize the actions of the police. This shows that the laws were not only ambiguous and ill-defined, but they were also subject to strategic use against the agents of the law. The defense lawyers used the same procedure when trying to refute the charges in those cases in which groups of defendants were indicted

44. The vagrancy charges cited here relate to the defendant Izabel Tavares; AN, Série Processo Criminal da 8. ${ }^{a}$ Pretoria do Rio de Janeiro, OR.3776, March 1904. The defense statement was authored by Martinho José dos Prazeres.

45. Vagrancy case against the defendant Alzira Maria da Conceição; AN, Série Processo Criminal da 8. ${ }^{a}$ Pretoria do Rio de Janeiro, OR.7974, April I910. Defense statement authored by Serapião Alcides de Figueiredo. 


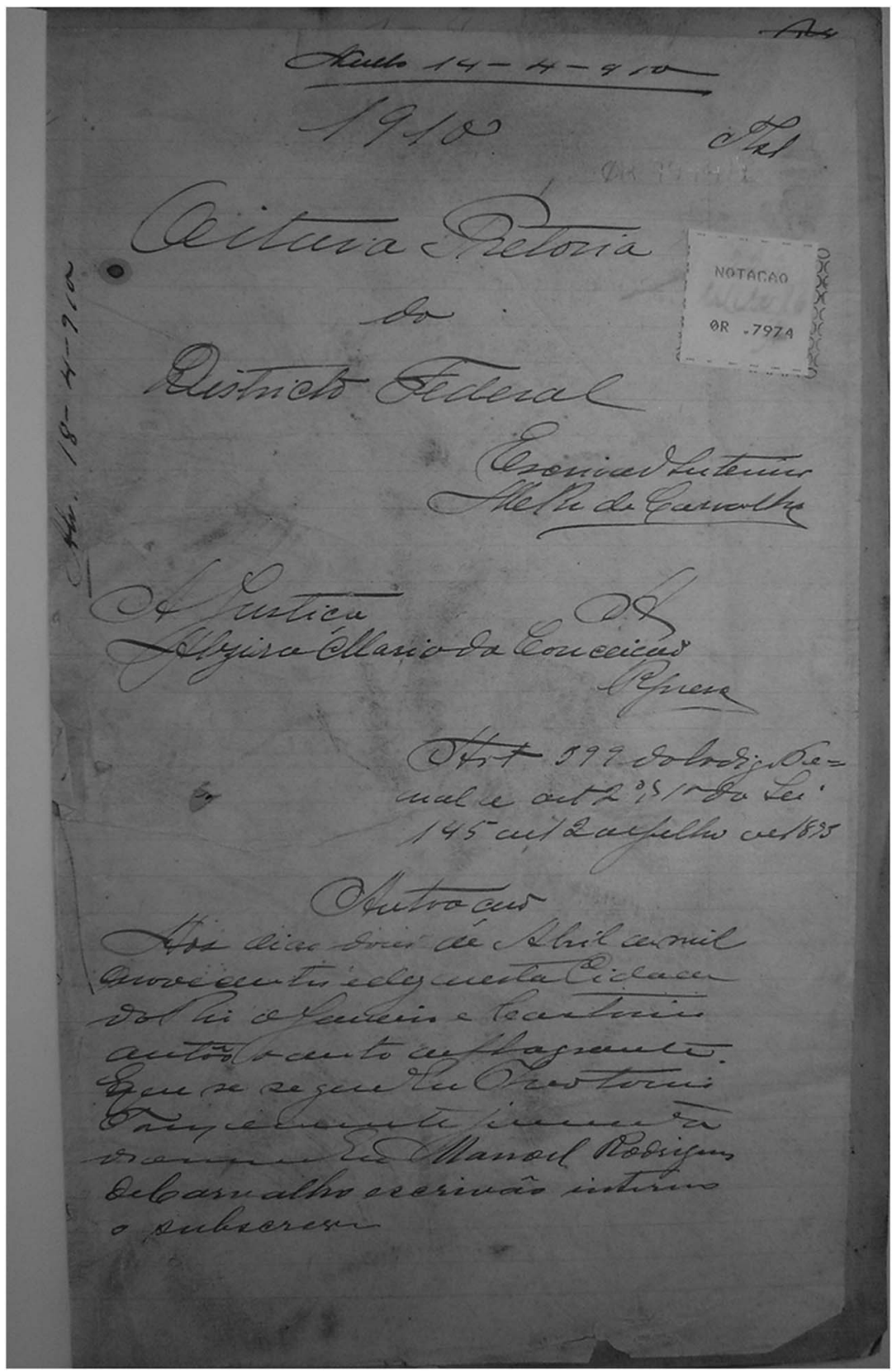

Figure I. Cover of the record of antecedents concerning the vagrancy case against the defendant Alzira Maria da Conceição.

AN, Série Processo Criminal da 8. ${ }^{a}$ Pretoria do Rio de Janeiro, OR.7974, April 1910. 
collectively rather than individually. In a 1906 case, the defendant's lawyer, Bruno Lemos, argued that:

Since criminal responsibility is an individual matter, according to the current law, it is clear that the prosecuting authority, in deciding on the case, ought to hear the witnesses about each individual defendant, and not all together, as occurs in the current proceedings. These irregularities have repeatedly led to the annulment of these cases. The extinct Civil and Criminal Tribunal always interpreted this way and absolved all the individuals who were tried in identical conditions to those which the accused here present experience, when they appealed the sentences to which they were condemned. And nobody better knows that than the current Eminent Judge who is to judge them, because when in exercise in the referred to court, he understood it that way, having with his vote acquitted many who were in the referred to conditions. ${ }^{46}$

In a trial from the previous year, Arthur Godinho took up the same arguments:

In this current trial, where three women are being charged, in violation of the express letter of law in article 25 of the Penal Code, which states that criminal responsibility is individual, which means that when witnesses testified in such hearings, they must testify about each defendant in himself; and the extinct Tribunal Civil and Criminal understood the law in this manner, such that these cases were successfully appealed, ordering the accused in these cases to be set free. And nobody knows this better than the Eminent Judge who presides over the present case, because when he was acting in the aforementioned Tribunal $[. .$.$] he$ understood it thus. ${ }^{47}$

In these two defense statements, the men referred back to the question of criminal responsibility and how it was treated in the judicial proceedings. Once again, legalities are cited to contest the actions of the police. The men who took up this line of argument in defense of the women being charged with vagrancy not only knew of the repeated dismissals which they used to their clients' advantage but also made more personal appeals, reminding the "Eminent Judge" Luiz Augusto de Carvalho e Mello, who would occupy the judgeship in Santana until I9II, that his decisions should remain consistent with positions he had taken in the past. The actual question of vagrancy appears to have remained at the margins of this discussion, since it was not the substance of the witnesses' testimony that was being questioned but rather the way in which the testimony had been obtained. These arguments made to contest the practice of judicial proceedings against groups

46. Vagrancy case against the defendant Inácia Maria da Conceição and others; AN, Série Processo Criminal da 8. Pretoria do Rio de Janeiro, OR.4347, January 1906. The defense statement was authored by Bruno Lemos.

47. Vagrancy case against the defendant Olga Maria de Souza Lima and others; AN, Série Processo Criminal da 8. ${ }^{a}$ Pretoria do Rio de Janeiro, OR.4357, July 1905. The defense statement was authored by Arthur Godinho. 


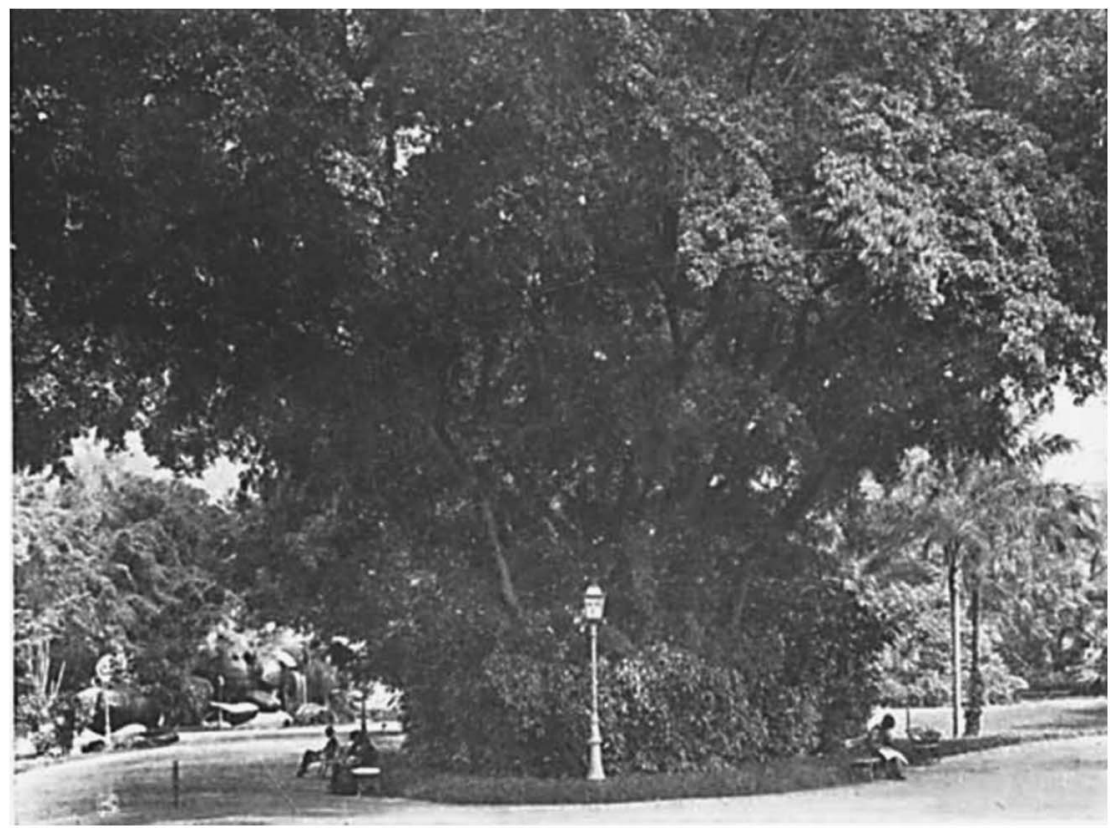

Figure 2. Praça da República, Rio de Janeiro, RJ, 1906.

Recenseamento do Rio de Janeiro (Districto Federal) realizado em 20 de setembro de 1906. Rio de Janeiro: Officina da Estatística, 1907.

of multiple defendants contributed to limiting the common policing practice in relation to the repression of vagrancy already mentioned before, the famous canoas.

The renowned writer João do Rio witnessed one of these occurrences when a police district chief invited him to visit one of the "hell holes" of the city. ${ }^{48}$ The chronicler described this sojourn in the narrative Sono Calmo ("Calm Sleep"), recalling that Oscar Wilde and Jean Lorrain as well as French reporters had made similar outings, therefore making his trip to the city's darker side "a most literary and newsworthy" undertaking. After describing his walk through a boarding house, he related that:

At this moment there was a cry "Grab him!". A boy ran. The lieutenant flew into action. Already two police officers ran at a dash. It was the hunt for the boys, the "canoa" was on its way. They had grabbed some twenty tramps, and one could watch

48. João do Rio was a pseudonym of the reporter and writer Paulo Barreto, who was born and lived in Rio de Janeiro. He wrote for different newspapers and authored a number of books between the end of the nineteenth and the beginning of the twentieth century. On his works, see Orna Messer Levin, As figurações do Dândi: um estudo sobre a obra de João do Rio (Campinas, 1996). 
there on the sidewalk a macabre snake, arrested, followed by police soldiers, a series of miserable tremors of terror uncoiling. ${ }^{49}$

The police did not bother to open a case for many of the "tramps" captured in these operations, leaving them irregularly detained for indefinite periods. In the cases where police did initiate formal judicial proceedings, they lumped together many into one document, an act that could, as seen above, generate criticisms from lawyers. In the press, however, some descriptions emphasized the positive nature of these canoas, mainly in the immediate aftermath of a large anti-vaccination riot, the so-called Revolta da Vacina, that occurred in November 1904 in the capital of the Republic. ${ }^{50}$ At the beginning of 1905 , under the headlines " Canoa' louvável" ("Praiseworthy Canoa"), "Canoas Moralizadoras" ("Moralizing Canoas"), and "Prisões" ("Arrests"), the Correio da Manhã newspaper praised the efforts of the suburban police stations: ${ }^{5}$

Last night, Inspector Câmara, with the laudable desire of making Meyer morally hygienic, undertook one of these memorable "canoas" managing to net six miscreants, ragged and of the most dangerous type. May those of the sixteenth [police district] proceed in this moralizing undertaking and the inhabitants of their zone will have more than enough reason to applaud it.

Associating canoas with necessary measures for "moral hygiene" and highlighting the dangerousness of their targets, the newspaper considered it important to encourage the continuation of this practice. Significantly, this newspaper was generally not inclined to endorse the police and never hesitated to publish criticisms or to denounce violent or inefficient police action. In truth, the positions of the newspapers varied according to their political alignment and the respective moment. In a defense statement presented in 1919, the defender of a "tramp" made use of precisely those times when the press took an anti-police stance. ${ }^{52}$ In addition to including in his defense case declarations proving the residency and occupation of the accused women and criticizing the fraudulent procedures in which the police had engaged, the defense also submitted clippings from O Jornal, published only days before, on 19 and 24 August 1919. The first clipping

49. João do Rio, A alma encantadora das ruas (Rio de Janeiro, I995 [1908]), p. I 24.

50. The Revolta da Vacina [revolt of the vaccine] was a popular uprising against the law that made vaccination against smallpox obligatory in the city of Rio de Janeiro. For several days, streetcars were overturned and barricades were raised. For an interesting debate on this uprising, see Leonardo Pereira, As barricadas da saúde: vacina e protesto popular no Rio de Janeiro da Primeira República (São Paulo, 2002).

5I. Articles published I7 March 1905, I8 March 1905, and 21 March 1905, respectively. For a description of a canoa undertaken by the ninth urban district (Santana), see "Gatunos Presos" ("Thieves Arrested") in the same newspaper from 22 February 1907.

52. Vagrancy case against the defendant Flora Ribeiro; AN, Série Processo Criminal da $3 .{ }^{a}$ Pretoria Criminal do Rio de Janeiro, 6Z.4949, August I919. 
came from the paper's front page featuring a story describing how the Inspector of Public Security himself had proposed measures to control the arbitrariness of these police procedures. The second was part of a police column where the full text was reproduced of the decisions of two judges who had dismissed cases involving fraud and irregularities.

If some defenses centered almost exclusively on the lack of respect for formal aspects, others featured criticism of both the form and the content of these criminal cases, contesting what it meant to be caught in the act of vagrancy, and the ways in which article 399 of the Penal Code was invoked. In 1909, Fernando Lupper Fortes Teixeira argued:

Nonetheless, dealing with the eyewitnesses it is noteworthy, and indeed strange, that just by the fact that a person is wandering about the taverns one cannot arrive at the tacit conclusion that this person is an incorrigible vagrant, and the most prescient proof can be found in the present case, in which the accused was employed and resided on 25 Luiz de Camões Street (as per the proof provided in the declaration and attached documents); to make purchases needed for her to carry on her trade she must wander daily about the taverns located on the perimeter of the Fourth Police District to buy grains for the best price.

The testimony of the witnesses in these proceedings is therefore false, as is the accusation of an infraction of the law, not only by virtue of the denial made by the accused woman in the police station itself, but also by the evident conflict between the criminal charges and the proof of her innocence that she has documented. ${ }^{53}$

Initially, the author of this defense criticized the way in which the witnesses deduced Maria Rosa's vagrancy. He dissociated the act of "wandering through the taverns" with being "an incorrigible tramp", referring to the sections of article 399 relevant to the importance of having an occupation and a residence, both of which the accused woman could prove, and leaving aside the question of morality the witnesses had raised. The emphasis rested on the evidence provided in this case concerning the defendant's daily life. The author of this defense statement thus lent another meaning to the accused woman's presence in the taverns.

It was necessary for any woman engaged in domestic work to frequent these places; the facts presented in this case served to prove that, in addition to holding a job, Maria Rosa was prudent and attended to her employers' interests by seeking the best prices. Although the criminal proceedings were taking place in the police station of Sacramento in the Fourth Police District, a part of the city that had been well known since the middle of the nineteenth century for so-called "window-prostitution" (prostituição de janela), with prostitutes who "solicited from the windows" of

53. Vagrancy case against the defendant Maria Rosa de Lima; AN, Série Processo Criminal da 8. ${ }^{a}$ Pretoria do Rio de Janeiro, OR.7703, June 1909. Defense statement authored by Fernando Lupper Fortes Teixeira. 
whorehouses, ${ }^{54}$ the defense showed that wandering about the taverns was legitimate and reflected favorably on the woman in question, who was transformed with a single twist, but using the same evidence, from a vagabunda into a woman at work.

The idea that being in the streets was evidence of honest work rather than deviancy can also be seen in other arrest records from Rio's Santana district. In July igos the court-appointed legal representative (curador) for two accused women who were under the age of twenty-one emphasized that one of them "has a job as a profession, which is that she is a cook, and she is presently unemployed because of her [...] health and was, just by chance, conversing with the other two accused women when the inspector arrested them";" with respect to the other defendant, the curador said that: "if she was found on General Pedra street it was because she naturally had gone to look for medicine or to make some other type of purchase". The third accused woman spoke in her own defense, and "declared that when others who walk in the streets going about their business were accused [of vagrancy], then she [was a vagrant] too, since she was just talking when a fat Inspector that they call Bairão arrested her with her two companions”. In the lack of the assistance of the court-appointed attorney, who used the first defendant's ill health to justify her presence in the street and her unemployed status, the third woman stated that like other people she had her "business" to attend to which required her to be in the streets.

Evidently, the accused women and their attorneys were continually pressed to offer explanations for circulating around the city, since the association between public space and immorality was recurrent in that period and used by the police to justify arrests that they, perhaps, knew themselves were unfounded. As the defense attorneys themselves alleged, policemen probably had some familiarity with the daily activities of these women and also knew that it was impossible for many of them to disprove vagrancy by having an address and a job. This would be brought out in some of their defense statements, for instance:

The accused, illiterate black women, live from their labor, as a cook and as a laundress, living under the roof of their bosses - how would it, consequently, be possible to offer a receipt for payment of rent as proof that they have a fixed abode?

They were unemployed due to the crisis, and they were looking for a job on the occasion of their arrest - such that, at the moment of their arrest they had with

54. On "window prostitution", see Cristiana Schettini Pereira, "Que tenhas teu corpo": uma história social da prostituição no Rio de Janeiro das primeiras décadas republicanas (Rio de Janeiro, 2006), ch. I.

55. Vagrancy case against the defendant Olga Maria de Souza et al.; AN, Série processo criminal da 8. pretoria do Rio de Janeiro, processo OR.4357, July 1905. 
them the [newspaper] Jornal do Commercio where they had indicated in pencil the streets where they needed domestic servants.

How can they possibly put into effect the signed commitment to obtain honest work within Is days if one is arrested 24 hours after release, and later arrested again? ${ }^{56}$

What can be seen here is that a number of strategies could be employed simultaneously to make a case for the defense. The first was to comment on a common feature of these women's lives, the fact that they resided in their bosses' homes and therefore could not furnish receipts to prove where they lived. Thereafter, however, the attorney said that the accused women were unemployed, which implied that they had no employer and, in turn, no place to live, which was due to the "crisis", rather than by any ill will on the part of the accused. He assumed, therefore, that they had no job or residence when arrested but referred back to the idea of the "occasional vagrant", which released them from blame and was related to the conditions that poor women endured in general.

It is interesting to observe that the author began by saying that the case concerned "illiterate black women" (pretas analfabetas), and then affirmed that they held a newspaper with "markings on the streets where domestic servants were sought". These are contradictory statements that, on the one hand, seem to be intended to show the women as victims and to awaken compassion while, on the other, to emphasize their efforts to find work.

One can observe that there were different ways by which defense attorneys could express themselves when they chose to discuss the central clauses of article 399 that related to work, residence, and morality. In this last defense statement dating from I904, the counsel accepted that the accused women were unemployed but did so in such as way as to distance them from the stigma of being "tramps". Also, the court defender in the I905 case cited above (against Olga Maria de Souza and others) sought extenuating circumstances related to the defendant's health problems to explain why one of his clients were not working. Meanwhile, in Maria Rosa's defense statement from 1909, her attorney constructed a rather idealized image of a devoted and faithful female worker who frequented taverns in search of the best prices for her employers.

\section{FINAL CONSIDERATIONS}

The form that these written defenses of women arrested for vagrancy took changed over time. Between the end of the rgros and the beginning of the I920s, the presentation of "tramps" as upstanding workers and, above all,

56. Vagrancy case against the defendants Ambrosina da Soledade, Celina Maria de Jesus, Liberatina da Silva Bastos, and Maria da Conceição; AN, Série Processo Criminal da 8. Pretoria do Rio de Janeiro, OR.3371, August 1904. Defense statement authored by Alfredo Silva. 
reformed women became another recurrent feature of these defenses. In 1919, Manoel Gomes Pinto stated: "Nevertheless the accused woman has a job and fixed and specific abode, being completely reformed, assiduous at work, something that the police do not wish to admit, meeting all the norms and principles of law, whether before the laws, or before any principle of just and acceptable belief." 57

In another defense from I92 I, Joaquim de Lima composed a text in the name of Rosaria Soares da Costa, in the following terms:

As a defense, to smash what the witnesses for the accusation say, I present attached to the file for this judicial proceeding a declaration from my present employer, who states therein regarding my behavior that I was always decent, although the police who detained me say that I am a tramp, which was not proved in the official statements, as Sir Judge will see. The police arrested me when I went to search for clothes, and I had left the home of my boss where I live, and took me to the police station. Thus, Sir Judge, I am employed, I am not a tramp, and I have not been arrested for two years, which proves that I am reformed. I request that Your Excellency absolve me for the sake of Justice. ${ }^{58}$

In these two examples, the attorneys did not deny that the accused women had been arrested previously and they even recognized, implicitly, that their arrests had been justified. To show the accused women as exoffenders was a significant difference from the strategies employed until the beginning of the I9Ios which had avoided any reference to previous records. The rationale of this new line of argument was to emphasize that, if they had been "tramps" in the past, they had been regenerated and become "assiduous in work", and that they behaved exemplarily, as proved by the declarations submitted as part of the formal judicial proceedings. According to the defense attorneys cited above, no motive could thus justify these women's arrests at that actual moment, other than the incompetence and the persecution of the police. The association between work and decency is very clear, as is the concern with emphasizing the latter through the accomplishment of personal reform.

In general, the tendency to present supposed "tramps" as working and decent women, which became a feature of these cases at the end of the I9Ios, implied accepting the most basic presuppositions established in

57. Vagrancy case against the defendant Constância Maria José; AN, Série Processo Criminal da 3. ${ }^{\text {a }}$ Pretoria Criminal do Rio de Janeiro, 6Z.4567, October 1919. According to record of the Gabinete de Identificação e Estatística attached to this document, Constância had been the defendant in eight legal cases between January I9Is and June I9I8, of which five were for vagrancy. Defense statement authored by Manoel Gomes Pinto.

58. Vagrancy case against the defendant Rosaria Soares da Costa; AN, Série Processo Criminal da 3. ${ }^{a}$ Pretoria Criminal do Rio de Janeiro, 6Z.6467, January I92 I. According to the record in the Gabinete de Identificação e Estatística, Rosária had been defendant in four trials between April I 9 I 2 and June 19I 8, three for vagrancy. Defense statement authored by Joaquim de Lima. 
article 399 (employment, residence, morality). It also implied not addressing the question of what constituted work and non-work, in other words, the specificities of women workers' lives. If in some measure these elements were discussed in the oral or written arguments in previous years, this type of argument now virtually disappeared from the criminal records. In the case of the accused women, as we have seen, we cannot know what they would have said to defend themselves, since the authorities increasingly restricted these women's participating in their cases. For their part, the lawyers seemed to adapt to the changes in the way these criminal proceedings functioned. As the police became increasingly concerned with the formal aspects of these cases, lawyers appear to have abandoned the approach that they had taken in the early years of the twentieth century. In its place, they supported their cases with documents that attested to employment and fixed residence, sometimes criticized the police, and almost always remarked on the good moral conduct of the accused women.

Pointing out these changes does not imply that the arguments of these men had a uniform meaning at any given time. After all, the potential defenders of these women were also not immune to the influence of regulations and continously renewed interpretations of the law, especially with regard to the social danger that "tramps" and other inmates of the Casa de Detenção could represent. In this respect, it is worth viewing the text written by Arthur Godinho when he defended two female minors in 1905 :

May the Eminent Judge order that the accused women appear before him and he will easily verify the infamous persecution that the authorities have undertaken, proceeding against two girls who are each under eighteen years old as tramps and drunkards. It is not necessary to cast more than a glance at them to have a sure conviction of their ages. Well then, this authority who, wishing to appear correct and worthy of the greatest recognition, tosses two female minors into the depths of jail, in proximity to the most heinous and disgusting caste of social dregs of society and harasses them with outrageous privations [...].59

Even if it had been to defend the accused woman and to condemn the police, Godinho's words were marked by the prejudices of his time when he spoke of "the most heinous and disgusting caste of social dregs". His defense strategy denigrated the inmates of the Casa de Detenção emphasizing the social danger that they represented. Between prejudices and rereadings of the legal texts, the defenders of prosecuted recidivist women had recourse to different definitions of vagrancy, giving them multiple and sometimes contradictory meanings. In this context - while trying to use this in favor of women who were held to be "tramps" - between the last years of 
the I9IOs and the beginning of the I920s the lawyers examined here came to refer to the criteria listed in article 399 of the Penal Code in a way that revealed their partial acceptance of the reigning discourse on work.

\author{
TRANSLATED ABSTRACTS \\ FRENCH - GERMAN - SPANISH
}

Lerice de Castro Garzoni. Aux limites du non-travail. Travailleuses pauvres et définitions du vagabondage à Rio de Janeiro au début du vingtième siècle.

Cet article étudie comment les résidents à Rio de Janeiro au Brésil, au début du vingtième siècle, définirent le vagabondage. Les commentateurs du code pénal de I 890 tentèrent d'expliquer les dispositions de l'article sur le vagabondage, l'article 399, et son application. Evaristo de Moraes, juriste, essayiste et intellectuel publique de cette époque, consacra également plusieurs ouvrages à ce sujet, de même que des journalistes et des écrivains littéraires qui travaillaient dans la presse. Mais ces débats dans le monde lettré n'étaient pas séparés des opinions et actions de citoyens ordinaires, phénomène que l'on peut observer en lisant les poursuites pénales de femmes qui furent arrêtées pour infractions répétées de lois contre le vagabondage. Les interventions et arguments des accusées et de leurs défenseurs permettent d'observer comment le vagabondage revêtit de nouvelles significations et comment, au fil du temps, la relation entre ces femmes et le monde du travail évolua.

Traduction: Christine Plard

Lerice de Castro Garzoni. An den Grenzen zur Nichtarbeit: Arme Arbeiterinnen und Definitionen der Landstreicherei im Rio de Janeiro des früben 20. Jabrbunderts.

Der Beitrag diskutiert, wie die Einwohner Rio de Janeiros (Brasilien) im frühen 20. Jahrhundert die Landstreicherei definierten. Kommentatoren des Strafgesetzbuches von I 890 bemühten sich um eine Auslegung des Paragrafen zur Landstreicherei (\$399) und versuchten seine Anwendung zu klären. Auch Evaristo de Moraes, ein zeitgenössischer Jurist, Essayist und öffentlicher Intellektueller, widmete dem Thema mehrere Arbeiten, wie dies auch Journalisten und für die Presse arbeitende Schriftsteller taten. Dass diese Debatten unter den Gebildeten nicht von den Ansichten und Handlungen der Durchschnittsbürger zu trennen sind, zeigt sich an den Strafprozessakten über Frauen, die man aufgrund wiederholter Verstöße gegen den Landstreichereiparagrafen verhaftet hatte. An den Interventionen und Argumenten der Beschuldigten und ihrer Verteidiger lässt sich erkennen, wie die Landstreicherei neue Bedeutungen annahm und wie sich das Verhältnis zwischen den Frauen und der Arbeitswelt im Laufe der Zeit entwickelte.

Übersetzung: Max Henninger 
Lerice de Castro Garzoni. En las fronteras del no-trabajo: las mujeres trabajadoras pobres y las definiciones de vagancia en Río de Janeiro a comienzos del siglo XX.

En este artículo se plantea cómo los habitantes de Río de Janeiro, Brasil, en los primeros años del siglo XX, definieron la vagancia. Quienes dedicaron comentarios al Código penal de i 890 buscaron explicar los términos y la aplicación del artículo relativo a la vagancia, el artículo número 339. En la misma línea que Evaristo de Moraes, un abogado, ensayista e intelectual público en ese momento, otros periodistas y escritores que trabajaban para distintos periódicos, dedicaron algunos de sus trabajos a esta cuestión. Sin embargo, estos debates que se dieron en el ámbito letrado no se trataban de algo aislado respecto de las percepciones y acciones de la gente corriente - un fenómeno que puede ser observado leyendo el contenido de los procesos judiciales contra las mujeres que habían sido arrestadas debido a las repetidas infracciones de las leyes antivagancia. En las intervenciones y argumentos de las acusadas y de sus defensores es posible encontrar cómo la vagancia adquirió un nuevo significado y cómo evolucionó, a lo largo del tiempo, la relación entre esas mujeres y el mundo del trabajo.

Traducción: Vicent Sanz Rozalén 